\title{
Effect of adding iron to the AlSi7Mg0.3 (EN AC 42 100, A356) alloy
}

Dana Bolibruchová, LukášRichtárech

Department of Technological Engineering, Faculty of Mechanical Engineering, University of Žilina, Univerzitná 1, 010 26, Slovak Republic, Email: danka.bolibruchova@fstroj.uniza.sk

Iron is the most common and harmful impurity in aluminum casting alloys and has long been associated with an increase of casting defects. While the negative effect of iron is clear, itsmechanism is not fully understood. In generally,iron is associated with the formation of Fe-rich intermetallic phases. This article deals with different iron content in aluminum alloy A356. After castingswere in test samples observed intermetallic phases and influence of iron on another elements in alloy. This alloy was not inoculatedor modified. The negative influence of iron wasn't eliminated by "iron correctors". The main objective of this experiment was to determine of such iron content, which corresponds to the iron content of secondary aluminum alloy.

Keywords: iron, intermetallic phases, secondary aluminum alloy

\section{Acknowledgement}

This project is solved under the financial support of VEGA number 1/0363/13. Authors would like to thank for their support.

\section{References}

[1] TAYLOR, J.A. (2004). The effect of iron in Al-Si casting alloys, $35^{\text {th }}$ Australian Foundry Institute National Conference, Adelaide, South Australia, pp. 148-157.

[2] SAMUEL, A.M., SAMUEL, F. H., DOTY, H. W. (1996). Observation on the formation of $\beta$ - Al5FeSi phase in 319 type Al-Si alloys. Journal of Materials Science, Vol. 31, pp. 5529-5539

[3] ĎURNIKOVÁ, E., TILLOVÁ, E. (2011). Phase and structure characteristics of recycled AlZn10Si8Mg cast alloy. Journal for science research and production, Manufacturing Technology, Vol. 11, No. 11, pp. 70-76

[4] BRŮNA, M., KUCHARČÍK, L., SLÁDEK, A. (2013). Complex evaluation of porosity in A356 aluminium alloy using advanced porosity module. In Manufacturing Technology, Vol. 13, No. 1, p. 26-30

[5] HURTALOVÁ, L., TILLOVÁ, E. (2013). Elimination of the negative effect of Fe-rich intermetallic phases in secondary (recycled) aluminium cast alloy. In Manufacturing Technology, Vol. 13, No. 1, p. 44-50

[6] KEJZLAR, P. (2012). Structure and mechanical properties of Fe-25Al-5Zr and Fe-30 Al-5Zr intermetallic alloys. In Manufacturing Technology, Vol. 12, No. 13, p. 131-135

[7] PALM, M. (2005). Concepts derived from phase diagram studies for the strengthening of Fe-Al-based alloys. Intermetallics. Vol. 13, pp. 1286.

[8] TillovÁ, E., CHALUPOVÁ, M., HURTALOVÁ, L., ĎURNíKOVÁ, E. (2011). Quality control of microstructure in recycled Al-Si cast alloys. In Manufacturing Technology, Vol. 11, No. 11, p. 70-76

[9] MICHALCOVÁ, A., VOJTĚCH, D. (2012). Structure of rapidly solidified aluminium alloys. In Manufacturing Technology. ISSN 1213-2489. vol. 12, p.166-169

[10] LIPIŃSKI, T. (2011). Use Properties of the AlSi9Mg Alloy With Exothermical Modifier. In Manufacturing Technology. ISSN 1213-2489. vol. 11, p. 44-49

[11] SLÁDEK, A. - BOLIBRUCHOVÁ, D. - PASTIRĆÁK, R. - VAŠKO, I. (2010). The influence of antimony on the properties of AlSi7Mg0,3 alloy. In: Proceedings of $69^{\text {th }}$ world foundry congress. Hangzhou China. Pp $261-$ 266

[12] EPEREJEŠI, L. - MALIK, J. - EPEREJEŠI, Š - FECKO, D. (2013) Influence of returningmaterial on porosity of diecasting. In Manufacturing Technology., Vol.13,No.1, pp.36-39 